\title{
ROS-mediated genotoxicity of asbestos-cement in mammalian lung
} cells in vitro

\author{
Elke Dopp ${ }^{1}$, Santosh Yadav², Furquan Ahmad Ansari², Kunal Bhattacharya1,2, \\ Ursula von Recklinghausen ${ }^{1}$, Ursula Rauen ${ }^{3}$, Klaus Rödelsperger ${ }^{4}$, \\ Behnaz Shokouhi ${ }^{1}$, Stefan Geh ${ }^{1}$ and Qamar Rahman*2
}

Address: ${ }^{1}$ Institute of Hygiene and Occupational Medicine, University Hospital Essen, Germany, ${ }^{2}$ Fibre Toxicology Division, Industrial Toxicology Research Centre, Lucknow, India, ${ }^{3}$ Institute of Physiological Chemistry, University Hospital Essen, Germany and ${ }^{4}$ Institute of Occupational Medicine, University Hospital Giessen, Germany

Email: Elke Dopp - elke.dopp@uni-essen.de; Santosh Yadav - santyadava2002@yahoo.co.in; Furquan Ahmad Ansari - ansari@yahoo.co.in; Kunal Bhattacharya - kbmail1@rediffmail.com; Ursula von Recklinghausen - ursula.von.recklinghausen@uni-essen.de; Ursula Rauen - ursula.rauen@uni-essen.de; Klaus Rödelsperger - Klaus.Roedelsperger@arbmed.med.uni-giessen.de; Behnaz Shokouhi - nazsh76@yahoo.com; Stefan Geh - StefanGeh@web.de; Qamar Rahman* - qamar_15@sify.com

* Corresponding author

Published: 06 October 2005

Particle and Fibre Toxicology 2005, 2:9 doi:10.1186/1743-8977-2-9
Received: 23 March 2005

Accepted: 06 October 2005

This article is available from: http://www.particleandfibretoxicology.com/content/2/1/9

(c) 2005 Dopp et al; licensee BioMed Central Ltd.

This is an Open Access article distributed under the terms of the Creative Commons Attribution License (http://creativecommons.org/licenses/by/2.0), which permits unrestricted use, distribution, and reproduction in any medium, provided the original work is properly cited.

\begin{abstract}
Asbestos is a known carcinogen and co-carcinogen. It is a persisting risk in our daily life due to its use in building material as asbestos-cement powder. The present study done on V79-cells (Chinese hamster lung cells) demonstrates the cytotoxic and genotoxic potential of asbestos-cement powder (ACP) in comparison with chrysotile asbestos. A co-exposure of chrysotile and ACP was tested using the cell viability test and the micronucleus assay. The kinetochore analysis had been used to analyse the pathway causing such genotoxic effects. Thiobarbituric acid-reactive substances were determined as evidence for the production of reactive oxygen species. Both, asbestos cement as well as chrysotile formed micronuclei and induced loss of cell viability in a concentration- and time- dependent way. Results of TBARS analysis and iron chelator experiments showed induction of free radicals in ACP- and chrysotile exposed cultures. $\mathrm{CaSO}_{4}$ appeared to be a negligible entity in enhancing the toxic potential of ACP. The co-exposure of both, ACP and chrysotile, showed an additive effect in enhancing the toxicity. The overall study suggests that asbestos-cement is cytotoxic as well as genotoxic in vitro. In comparison to chrysotile the magnitude of the toxicity was less, but co-exposure increased the toxicity of both.
\end{abstract}

\section{Background}

Asbestos has been well documented to be a carcinogen and co-carcinogen associated with the induction of mesothelioma, lung cancers and other benign lung diseases $[1,2]$. 'Asbestos' is a generic term for a group of six natu- rally occurring fibrous silicate minerals. It is grouped into two major classes: Serpentine, which contains a magnesium silicate called chrysotile and Amphibole, which includes crocidolite, amosite, anthophyllite, actinolite and tremolite [3]. Asbestos has been used in more than 
3,000 products because of its high tensile strength, relative resistance to acid and temperature, varying textures and degrees of flexibility. It does not evaporate, dissolve, burn, or undergo significant reactions with other chemicals, which make asbestos non-biodegradable and environmentally cumulative. Over $95 \%$ of the total commercial asbestos use all over the world is chrysotile asbestos [4]. Chrysotile has the morphology of being curly and pliable [5]. Size, geometry, chemical composition and surface charge of various asbestos types play an important role in interactions with cells that lead to cell injury and disease $[6,7]$. Respiratory impairment, bronchial asthma, chronic bronchitis was noticed in asbestos cement factory workers [8]. However, in the case of chrysotile asbestos, its positive surface charge is more important than its morphology in rendering a toxic and lytic potential [9]. The iron content in chrysotile, primarily present as a surface contaminant [7] is low ( 1-6\%), but has to be considered in its toxicity.

Asbestos fibres in the environment can result from mining, milling and weathering of asbestos-bearing rocks, and from the manufacture, wear, and disposal of asbestoscontaining products [10]. Because of the widespread use of asbestos, its fibres are ubiquitous in the environment. Indoor air can become contaminated with fibres released from building materials, especially if they are damaged or crumbling. Common sources of asbestos in homes are ceilings, pipe insulation, boiler coverings, wallboard, floor, ceiling tiles, sheets, pipes and jointings, etc. Asbestos-cement products, e.g. roof tiles, contain as much as $11-12 \%$ of chrysotile asbestos. As a result of continuing exposure to the weather and to acid rain, the surface of asbestos-cement products becomes corroded and weathered. Cement particles, asbestos fibres and agglomerates of particles and fibres are therefore released from the surface and may be dispersed in air and water in large amounts [11].

The toxicity of asbestos is characterized by a number of processes, among which the production of reactive oxygen and reactive nitrogen species (ROS and RNS) are thought to be the most important ones. Highly reactive oxygen species such as the hydroxyl radical can be produced through Fenton-type reaction catalysed by iron impurities present on the surface. ROS/RNS are also produced in the lungs by the chronic inflammatory reaction produced by the prolonged phagocytic activity of macrophages against the bio-persistent fibres [12]. ROS/RNS can cause various types of DNA damages. The most extensively studied are lesion of 8-oxodeoxyguanosine (8-oxodGuo) or the corresponding base (8-oxoGua). These altered nucleotides can be detected in the DNA of cell lines of human or animal origin after treatment with asbestos fibres $[13,14]$.

Smailyte et al. [15] analyzed the cancer risk in Lithuanian cement producing workers and found that exposure to cement dust may increase lung and bladder cancer. He further reported a dose related risk for stomach cancer. Fatima et al. [16] have reported chromosomal abnormalities in asbestos cement factory workers. Rahman et al. [17] found chromosomal aberrations, sister chromatid exchanges and micronuclei formation in the blood lymphocytes of asbestos cement factory workers in comparison to their controls. Dušinská et al. [12] investigated chromosomal and DNA damage in former asbestos cement plant workers. As discussed above chrysotile is the most commercially exploited variety of asbestos and mostly used as asbestos-cement for building material. There are not many studies that assess the cyto- and genotoxicity of asbestos cement in vitro using cell lines. In the present study, we have investigated if asbestos-cement causes similar effects in cellular systems regarding cytotoxicity and genotoxicity than chrysotile asbestos. The micronucleus assay was applied to test the genotoxic effects of asbestos cement in V79-cells (Chinese hamster lung cells), an established cell culture model. Application of kinetochore analysis, radical measurements and iron chelator experiments gave more informations about the mechanistic background, which seems to be based on the formation of free radicals.

\section{Results}

Light microscopy showed the average percentage of fibre sizes in asbestos-cement samples to be $50.3 \%(<5-10$ $\mu \mathrm{m}), 31.2 \%(11-20 \mu \mathrm{m})$ and $18.5 \%(21-30 \mu \mathrm{m})$ and in chrysotile $49.7 \%(<5-10 \mu \mathrm{m}), 30.7 \%(11-20 \mu \mathrm{m})$ and $19.5 \%(21-30 \mu \mathrm{m})$ (Table 1). The cytotoxic potential of

Table I: Analysis of asbestos-cement and chrysotile samples using light microscopy (magnification: 2000x) Data represent the mean of 33 counting.

\begin{tabular}{|c|c|c|c|c|c|}
\hline \multirow[t]{2}{*}{ Sample } & \multirow{2}{*}{$\begin{array}{l}\text { WHO-fibres } \mathrm{F} / \mathrm{ml} \times \\
10^{6}\end{array}$} & \multirow[t]{2}{*}{$\%$ of fibres/sample } & \multicolumn{3}{|c|}{ Distribution of fibres according to the length (\%) } \\
\hline & & & $<5-10 \mu \mathrm{m}$ & $10-12 \mu \mathrm{m}$ & $20-30 \mu \mathrm{m}$ \\
\hline Asbestos cement & 144 & 12.8 & 50.3 & 31.2 & 18.5 \\
\hline Chrysotile & 697 & 100 & 49.7 & 30.7 & 19.5 \\
\hline
\end{tabular}


Table 2: Fibre counting by electron microscopy

\begin{tabular}{|c|c|c|c|c|c|c|c|}
\hline \multirow[t]{2}{*}{ Sample } & \multicolumn{3}{|c|}{ Suspension } & \multicolumn{3}{|c|}{ WHO-fibre counts } & \multirow{2}{*}{$\begin{array}{l}\text { TEM } \\
\text { Magnification, Number of fields }\end{array}$} \\
\hline & \multicolumn{2}{|c|}{$\mathrm{mg} / \mathrm{ml}$} & \multirow{2}{*}{$\begin{array}{c}\text { Filter deposit } \\
\mu g / \mathrm{cm}^{2}\end{array}$} & & \multirow{2}{*}{$\begin{array}{l}\mathrm{F} / \mathrm{mg} \\
\times 10^{6}\end{array}$} & \multirow{2}{*}{$\begin{array}{l}\mathrm{F} / \mathrm{ml} \\
\times 10^{6}\end{array}$} & \\
\hline & Original & Diluted & & $\mathrm{n}$ & & & \\
\hline \multirow[t]{2}{*}{ Asbestos cement } & II & 0.05 & 73.2 & 14 & 38.3 & 425 & $\times 10000,10$ fields \\
\hline & & & & 34 & 12.9 & 144 & $\times 2000,2$ fields \\
\hline \multirow[t]{2}{*}{ UICC-chrysotile } & 5 & 0.01 & 13.2 & 32 & 486 & 2432 & $\times 10000,10$ fields \\
\hline & & & & 33 & 139 & 697 & $\times 2000$, I field \\
\hline
\end{tabular}

asbestos cement, chrysotile asbestos and $\mathrm{CaSO}_{4}$ (negative control) was determined after an exposure time of 24, 48 and $72 \mathrm{hrs}$. The results show a decrease in cell viability of ACP- and chrysotile-exposed V79-cells with increasing fibre/dust concentrations and exposure times. The results showed chrysotile to be more cytotoxic than the ACP after 24, 48 and 72 hrs exposure (Figure 2). $\mathrm{CaSO}_{4}$ was seen to be negligibly cytotoxic up to the highest concentration $\left(20 \mu \mathrm{g} / \mathrm{cm}^{2}\right)$ and also did not have any effect at longer exposure times.

Figure 3 shows the level of induced micronuclei (MN) by ACP in V79-cells at 24, 48 and 72 hrs consecutively to a concentration of $1,3,5$ and $10 \mu \mathrm{g} / \mathrm{cm}^{2}$ of ACP. ACP induced a significant number of micronucleated cells at all applied concentrations after $24 \mathrm{hrs}$ and $48 \mathrm{hrs}$ of exposure with the highest induction at $5 \mu \mathrm{g} / \mathrm{cm}^{2}$ after $24 \mathrm{hrs}$. The reduced number of $\mathrm{MN}$ after 72 hrs exposure can be explained by increased cytotoxic effects at the applied ACP-concentrations. On comparing ACP to chrysotile the latter induced at a concentration of $1 \mu \mathrm{g} / \mathrm{cm}^{2}$ almost equal numbers of MN as ACP at a concentration of $3 \mu \mathrm{g} / \mathrm{cm}^{2}(\mathrm{p}$ $<0.01)$. The results of a co-exposure of ACP $\left(3 \mu \mathrm{g} / \mathrm{cm}^{2}\right)$ and chrysotile $\left(1 \mu \mathrm{g} / \mathrm{cm}^{2}\right)$ are shown in Figure 4. Additive effects can be seen through an increased formation of $\mathrm{MN}$ as compared to induction by ACP $\left(3 \mu \mathrm{g} / \mathrm{cm}^{2}\right)$ or chrysotile $\left(1 \mu \mathrm{g} / \mathrm{cm}^{2}\right)$ alone. The difference between ACP or chrysotile alone and co-exposed V79-cells is statistically not significant.

The kinetochore analysis revealed a slight increase in kinetochore-negative micronuclei in cells exposed to ACP (3 $\left.\mu \mathrm{g} / \mathrm{cm}^{2}\right)$, chrysotile $\left(3 \mu \mathrm{g} / \mathrm{cm}^{2}\right)$ and co-exposure of ACP (3 $\left.\mu \mathrm{g} / \mathrm{cm}^{2}\right)$ and chrysotile $\left(1 \mu \mathrm{g} / \mathrm{cm}^{2}\right)$ indicating clastogenic events $(p<0.05)$. However, the differences compared to the untreated control are statistically not significant. $\mathrm{CaSO}_{4}$ induced a negligible amount of kinetochore-negative micronuclei, which was almost equal to controls. Coexposure of ACP and chrysotile induced kinetochore-negative micronuclei almost equal to that induced by chrysotile $\left(1 \mu \mathrm{g} / \mathrm{cm}^{2}\right)$ alone (Table 3$)$.

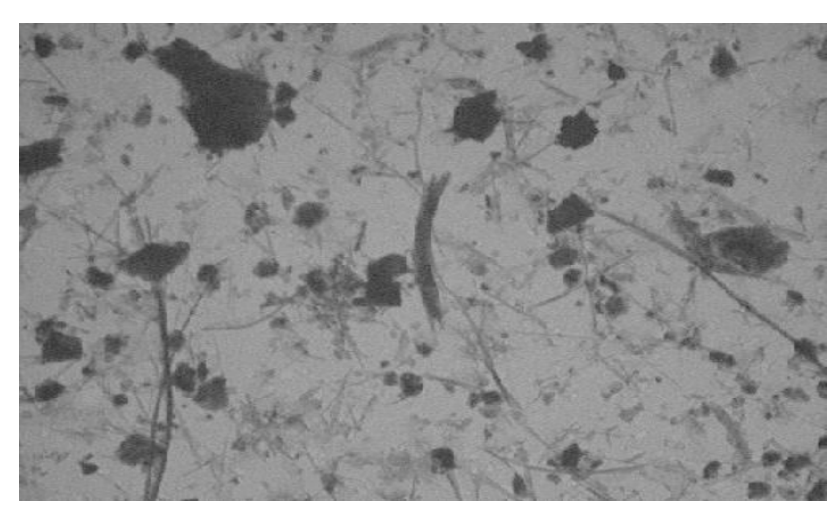

Figure 1 A

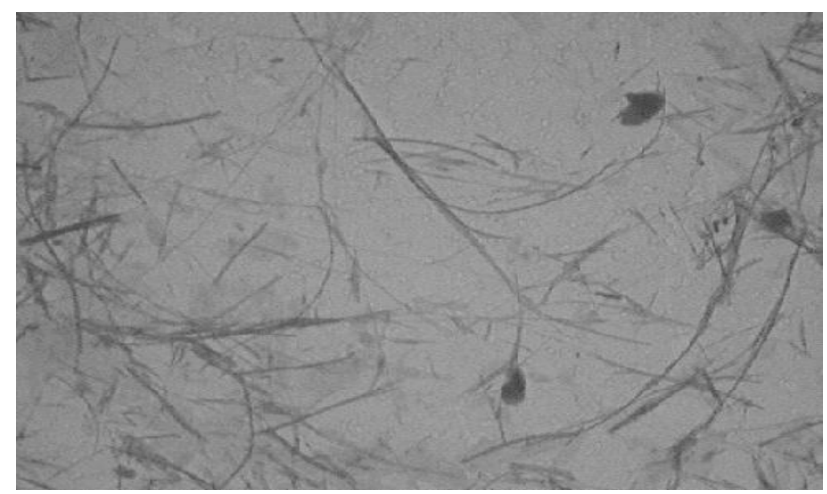

Figure 1 B

\section{Figure I}

Transmission electron microscopy pictures of asbestoscement (A) and chrysotile (B) samples. (Magnification: 2000x)

Addition of the iron chelators 2,2'-DPD and desferal reduced the number of induced micronuclei (see Fig. 4) to the control level or even lower (Figure 5). The iron chelators 2, 2' DPD and desferal are able to prevent radical formation in cellular systems by complexation of free metal 


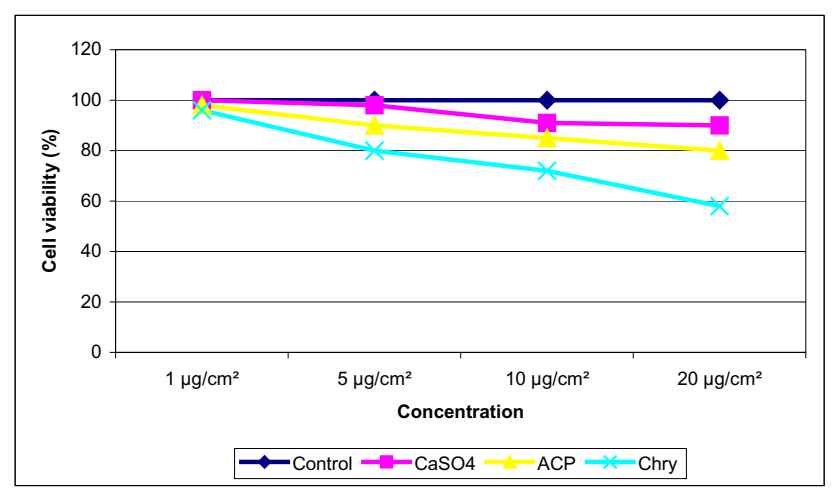

Figure 2 A

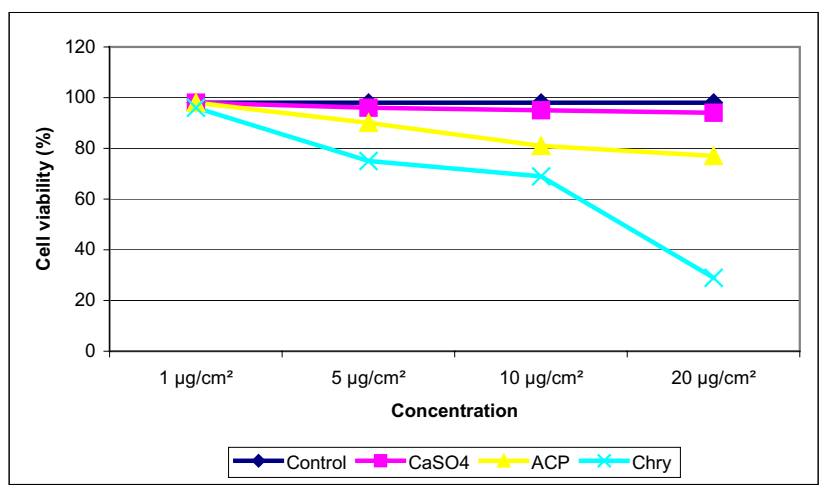

Figure 2 B

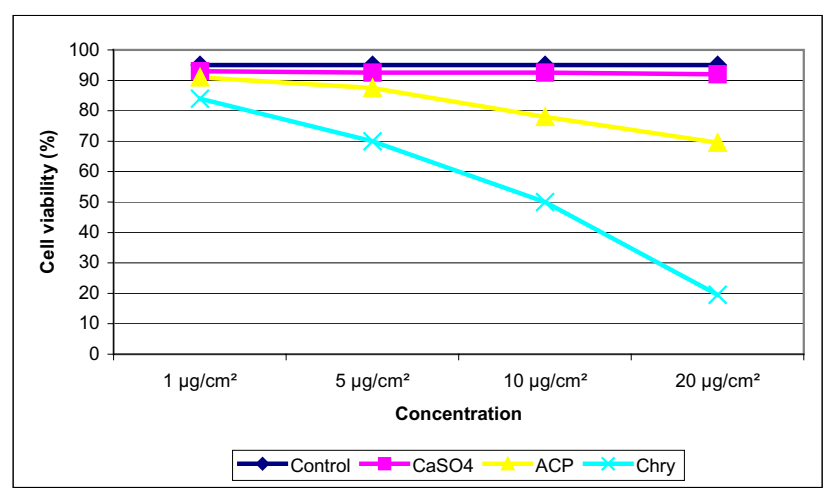

Figure 2 C

\section{Figure 2}

Cytotoxicity of asbestos-cement in V79-cells. Cells were treated with various doses $\left(\mathrm{I} \mu \mathrm{g} / \mathrm{cm}^{2}, 5 \mu \mathrm{g} / \mathrm{cm}^{2}, 10 \mu \mathrm{g} / \mathrm{cm}^{2}\right.$, $20 \mu \mathrm{g} / \mathrm{cm}^{2}$ ) of asbestos-cement and chrysotile for $24 \mathrm{hrs}$ (A), 48 hrs (B) and 72 hrs (C). The percentage of decreased cell viability is shown in relation to the untreated control. The cytotoxicity was determined by trypan bluestaining. The experiments were repeated twice. SD $<1 \%$ and iron ions. A stronger reducing effect in $\mathrm{MN}$-formation can be observed in chrysotile-exposed V79 cells compared to asbestos cement-exposed cells (Fig. 5A). However, application of desferal induced stronger reducing effects in ACP-exposed V79-cells (Fig. 5B). This reduction is statistically significant $(\mathrm{p}<0.05)$.

The formation of TBARS was detected in ACP, chrysotile and co-exposed (ACP and chrysotile) V79-cells (Figure 6). $\mathrm{Fe} / 8 \mathrm{HQ}(1.6 \mu \mathrm{l} / \mathrm{ml})$ was used as positive control and induced TBARS formation up to $0.25 \mathrm{nmol} / \mathrm{mg}$ protein. After 24 h exposure to ACP or chrysotile, V79-cells started to release low levels of TBARS, which enhanced in quantity longer exposure times of $36 \mathrm{~h}(0.063 \mathrm{nmol} / \mathrm{mg}$, ACP) and $48 \mathrm{~h}(0.089 \mathrm{nmol} / \mathrm{mg}$, chrysotile), respectively. We observed a delayed formation of TBARS after co-exposure of V79-cells to ACP and chrysotile after $72 \mathrm{~h}$ exposure time $(0.089 \mathrm{nmol} / \mathrm{mg}$ ) (Figure 6).

\section{Discussion}

The present study demonstrates a time- and concentration- dependent loss of cell viability in chrysotile-exposed V79-cells. These results are in agreement to those found by Hong and Choi [18] in V79-cells. The genotoxicity analysis using micronuclei $(\mathrm{MN})$ as biomarker proved that chrysotile gave a maximum damage to the cells at relatively low concentrations. Similar observations were also found in our earlier studies done with human mesothelial cells (HMC) [19-21] and human peripheral blood lymphocytes [22]. The studies suggest that clastogenic factors are responsible for the genotoxic effect shown as kinetochore-negative MN. In the past Dopp et al. [23], Dopp and Schiffmann [24], Rahman et al. [3] and Poser et al. [21] have shown that clastogenic events caused by chrysotile are responsible for the formation of micronuclei in different cell types. The results of the TBARS analysis in the present study further strengthened chrysotile-induced clastogenic events by suggesting the release of free radicals. The present study showed AC-induced release of TBARS (evidence for lipid peroxidation) after $24-48 \mathrm{hrs}$ exposure. The highest amount of MN induction in V79cells was also found during this period demonstrating an interrelation between these two features. In the case of chrysotile asbestos, a delayed release of TBARS (> 24 hrs exposure) can also be observed. These findings are in concordance with findings of Burmeister et al. [25]. These authors did not observe an increase in Fpg-sensetive sites indicative of oxidative DNA-base modification in asbestos-treated human mesothelial cells up to an exposure time of 24 hrs. Abidi et al. [26] and Afaq et al. [27] reported about the production of high amounts of TBARS and alteration of the GSH redox system by chrysotile fibres. Kopnin et al. [28] showed that fibroblasts as well as mesothelial cells are able to generate reactive oxygen species (ROS) in response to asbestos exposure whereas 


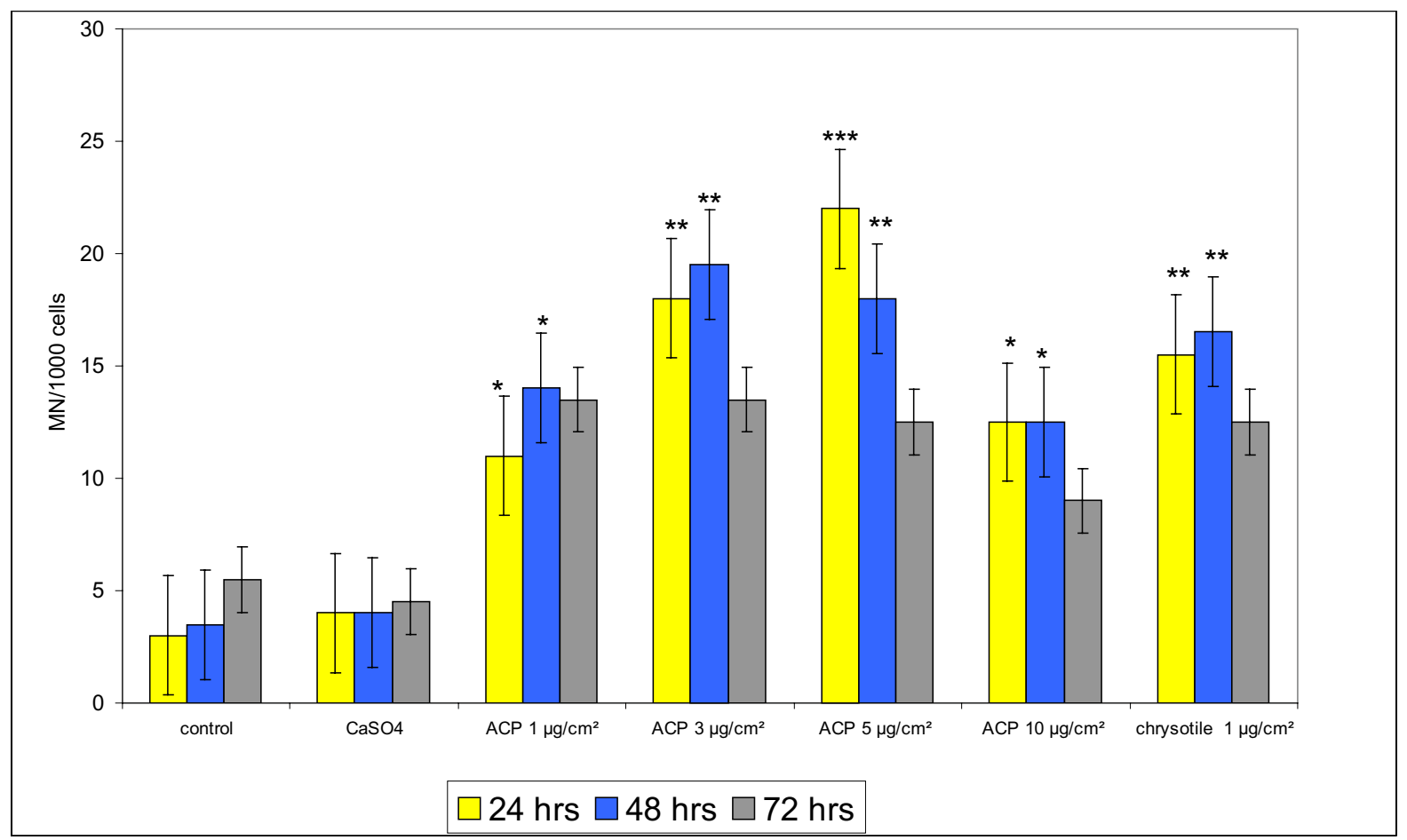

\section{Figure 3}

Micronucleus induction after exposure of V79-cells to different doses of asbestos-cement for 24, 48 and 72 hrs. The experiment was repeated twice. Significance: $* p<0.05,{ }^{*} p<0.01$, *** $p<0.001$.

fibroblasts have a lower ability to produce ROS compared to mesothelial cells.

ACP induced pronounced cytotoxicity and genotoxicity in V79-cells, even though its toxic effects were lower than that of chrysotile both in dosage and induction levels. Tilkes and Beck [29] reported similar findings on macrophages in which asbestos cement caused lower cytotoxicity than UICC-chrysotile. Exposure to the different concentrations of ACP showed increased formation of micronuclei in V79-cells.

The co-exposure of V79-cells to ACP and chrysotile resulted in a weak additive effect. However, the amount of induced kinetochore-negative MN did not vary much from that induced by chrysotile. In summary, it can be stated that both ACP and chrysotile have cytotoxic and genotoxic properties. However, the toxicity of chrysotile is more pronounced than that of ACP. The co-exposure (ACP and chrysotile) of V79-cells showed weak additive genotoxic effects. The release of TBARS in ACP- and chrysotile exposed V79-cells suggests the involvement of free radicals in fibre/dust-induced toxicity.

\section{Methods}

\section{Fibres and dust samples}

Asbestos cement powder (ACP) was prepared from asbestos cement sheet by grinding with mortar and pestle (Industrial Toxicology Research Centre, Lucknow, India). The main type of asbestos fibre in the ACP-sample is chrysotile asbestos (12.8\% fibres/sample, Tab. 1). The sample was sieved through a $30 \mu \mathrm{m}$ brass sieve. Sterilization was carried out at $120^{\circ} \mathrm{C}$ for 2 hours (hrs) and the samples were subsequently suspended in sterile PBS buffer. The suspensions were analysed by transmission electron microscopy (Hitachi H600) according to fibrous and nonfibrous material and the number of fibres $/ \mathrm{ml}$ were calculated according to the counting rules of VDI 3492 (VDI Richtlinie, 1994) (Tab. 2). Further fibre and particle analyses were carried out using light microscopy [30] and transmission electron microscopy (TEM, Phillips). TEM pictures of asbestos-cement and chrysotile samples are shown in Fig. 1 (magnification: 2000×). The large nonfibrous conglomerate material in Fig. $1 \mathrm{~A}$ represents agglomerates of cement particles. 


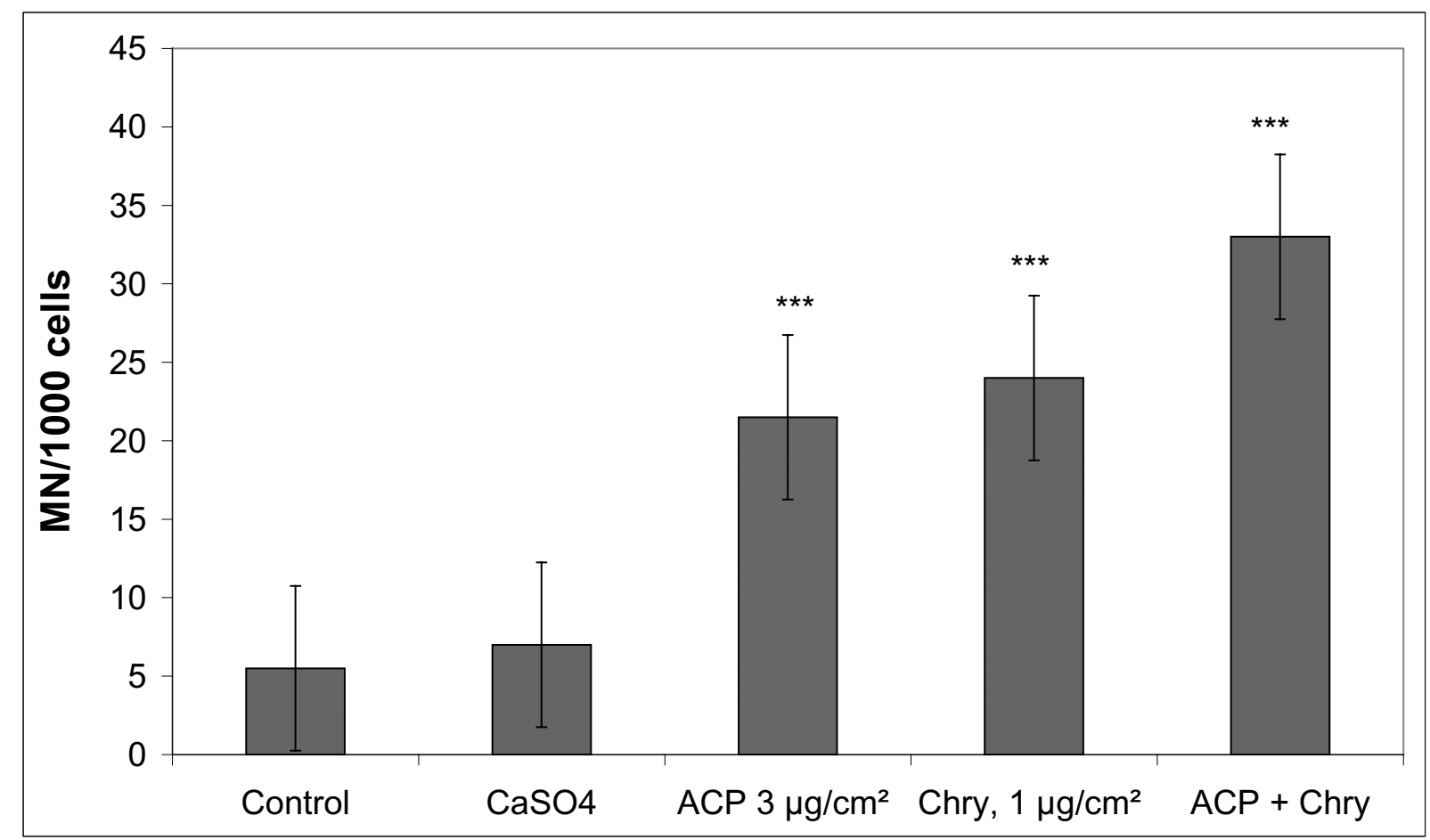

\section{Figure 4}

Micronucleus induction in V79-cells after co-exposure of asbestos and asbestos- cement (chrysotile: I $\mu \mathrm{g} / \mathrm{cm}^{2}, \mathrm{ACP}: 3 \mu \mathrm{g} / \mathrm{cm}^{2}$; exposure time: $48 \mathrm{~h}$ ). The experiment was repeated twice. Significance: $* * * p<0.001$.

Table 3: Kinetochore analysis after exposure of V79-cells to asbestos cement, chrysotile and gypsum (negative control) for $48 \mathrm{~h}$. The experiment was repeated twice.

\begin{tabular}{ccc}
\hline Samples & No of scored MN & Mean K- (士 SD) \\
\hline Control & 200 & $68.5 \pm 0.70$ \\
$\mathrm{CaSO}_{4}\left(3 \mu \mathrm{g} / \mathrm{cm}^{2}\right)$ & 200 & $67 \pm 2.12$ \\
Asbestos cement $\left(3 \mu \mathrm{g} / \mathrm{cm}^{2}\right)$ & 200 & $71.5 \pm 1.4$ \\
Chrysotile $\left(1 \mu \mathrm{g} / \mathrm{cm}^{2}\right)$ & 200 & $73.5 \pm 0.70$ \\
Co-exposure $\left(3 \mu \mathrm{g} / \mathrm{cm}^{2} \mathrm{ACP}\right.$ and I $\mu \mathrm{g} / \mathrm{cm}^{2}$ & 200 & $75 \pm 2.8$ \\
chrysotile) & & \\
\hline
\end{tabular}

A final concentration of asbestos cement powder (ACP) in PBS (phosphate buffered saline) of $1.1 \mathrm{mg} / \mathrm{ml}$ was used. Chrysotile (UICC) and commercially available $\mathrm{CaSO}_{4}$ (Sigma, Taufkirchen, Germany) were applied as positive and negative controls, respectively.

\section{Cell culture}

V79-cells (Chinese hamster lung fibroblast cells) were obtained from ECC (European Collection of Cell Cultures, ECC No.: 86041102). Cells were cultivated in RPMI-1640 (Gibco) with Fetal Calf Serum (10\%) (Gibco), L-glutamine (1\%) (Gibco) and antibiotics (100 $\mathrm{U} / \mathrm{ml}$ penicillin and $100 \mu \mathrm{g} / \mathrm{ml}$ streptomycin) (Gibco) at $37^{\circ} \mathrm{C}$ and $5 \% \mathrm{CO}_{2}$. 


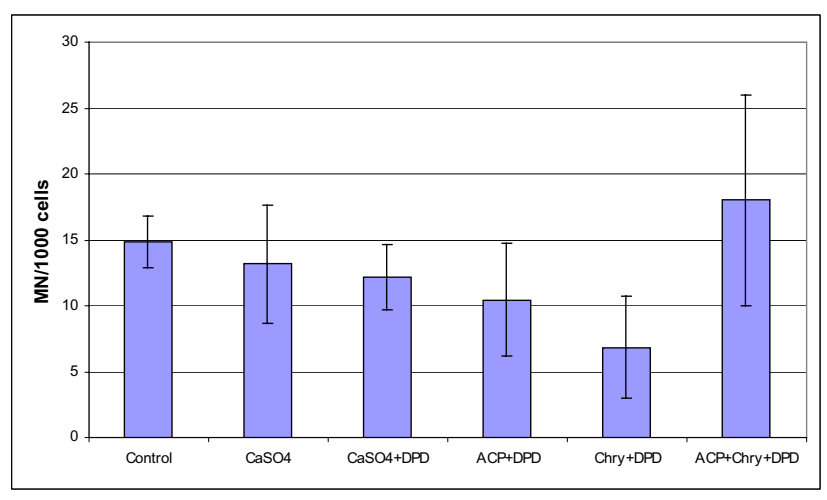

Figure $5 \mathrm{~A}$

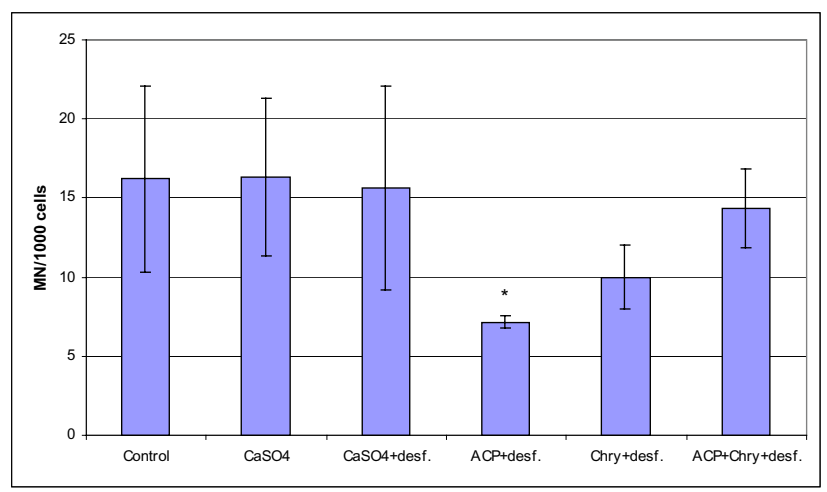

Figure 5 B

\section{Figure 5}

Reduction of micronucleus formation in exposed V79-cells after addition of the iron chelators 2,2'-dipyridyl (final concentration: $100 \mu \mathrm{M})(\mathbf{A})$ and desferal (final concentration: $100 \mu \mathrm{M})$ (B). The treatment of cells with $2,2^{\prime}$-DPD and desferal, respectively, was done simultaneously with the fiber and particle treatment (concentrations: $3 \mu \mathrm{g} / \mathrm{cm}^{2} \mathrm{CaSO}_{4} ; 3$ $\mu \mathrm{g} / \mathrm{cm}^{2}$ asbestos cement; I $\mu \mathrm{g} / \mathrm{cm}^{2}$ chrysotile; exposure time: $48 \mathrm{~h})$.

\section{Cytotoxicity test}

V79-cells (state of confluence: max. 70\%) were treated with $\mathrm{ACP}, \mathrm{CaSO}_{4}$ and chrysotile, respectively, at different doses $\left(1 \mu \mathrm{g} / \mathrm{cm}^{2}-10 \mu \mathrm{g} / \mathrm{cm}^{2}\right)$ for $24 \mathrm{hrs}, 48 \mathrm{hrs}$ and 72 hrs. Cell viability was evaluated immediately after exposure. Treated and untreated cells were harvested by trypsin treatment (Sigma). Cell counting was performed following trypan blue staining. The cell suspension was mixed with an equivalent volume of $0.4 \%$ trypan blue solution (Sigma) and subsequently evaluated under the light microscope. The membrane of dead cells is permeable to trypan blue (blue stained cells), whereas living cells remain unstained. Cell viability is expressed as percentage of surviving cells compared to the total number of cells. A substance is considered to be cytotoxic if the decrease in cell viability is $\leq 50 \%$.

\section{Micronucleus assay and kinetochore analysis}

For micronucleus $(\mathrm{MN})$ analysis, $2 \times 10^{5}$ V79-cells were seeded in each well of Quadriperm-dishes (Viva-Science, Sartorius, Göttingen, Germany) and cultured overnight. Then the fibre and dust samples were applied for $24 \mathrm{hrs,}$ 48 hrs or 72 hrs at different concentrations. At the end of the exposure times cells were fixed and stored in cold methanol $\left(-20^{\circ} \mathrm{C}\right)$ for at least 30 minutes before staining. For micronucleus assay the cells were washed with PBS/ CMF (calcium- and magnesium-free phosphate buffered saline) and the nuclei were stained with bisbenzimide (Hoechst 33258, concentration: $5 \mu \mathrm{g} / \mathrm{ml}, 4$ minutes). The slides were then mounted for fluorescence microscopy and examined for the presence of micronuclei. Each data point represents the mean of 3 treated cultures from different experiments with 2000 nuclei evaluated in each case. The significance was tested by using the $\mathrm{Chi}^{2}$-test.

For further analysis of the induced micronuclei after treatment of cells with ACP or chrysotile, kinetochores were stained by incubating the fixed cell preparations with CREST antibodies (Chemicon, Temecula, CA, U.S.A.) for $1 \mathrm{hr}$ in a humidified chamber at $37^{\circ} \mathrm{C}$. After rinsing with PBS with $0.5 \%$ Tween 20 (Sigma, Germany), the cells were incubated with fluorescein isothiocyanate (FITC)conjugated anti-human IgG (Antibodies Incorporated, Davis, USA) for $30 \mathrm{~min}$ before applying bisbenzimide. At least 200 micronuclei were examined for the presence of kinetochores in each case. The significance was tested by using the $\mathrm{Chi}^{2}$-test.

\section{Application of iron chelators}

The iron chelators 2,2'-dipyridyl (DPD) (Fluka, Germany) and desferal (Novartis, Germany) were used to investigate the reduction of the particle induced genomic effects by binding to metal/iron ions. Herewith, the formation of free radicals can be reduced. DPD (final concentration: $100 \mu \mathrm{M}$ ) and desferal (final concentration: $10 \mathrm{mM}$ ) were dissolved in $\mathrm{ddH}_{2} \mathrm{O}$ and added to the culture medium. The treatment of cells with DPD or desferal was done simultaneously with the fibre/dust treatment (concentrations: ACP $3 \mu \mathrm{g} / \mathrm{cm}^{2}$, chrysotile $1 \mu \mathrm{g} / \mathrm{cm}^{2}, \mathrm{CaSO}_{4}$ as negative control $3 \mu \mathrm{g} / \mathrm{cm}^{2}$, exposure time: $48 \mathrm{hrs}$ ).

\section{Radical measurement}

Thiobarbituric acid-reactive substances (TBARS) were determined as indication for the formation of reactive oxygen species. TBARS were determined in the supernatant after various incubation times. V79-cells were cultivated in Ham's F12 culture medium for 24 hrs. The cells were then exposed to asbestos cement $\left(3 \mu \mathrm{g} / \mathrm{cm}^{2}\right)$, 


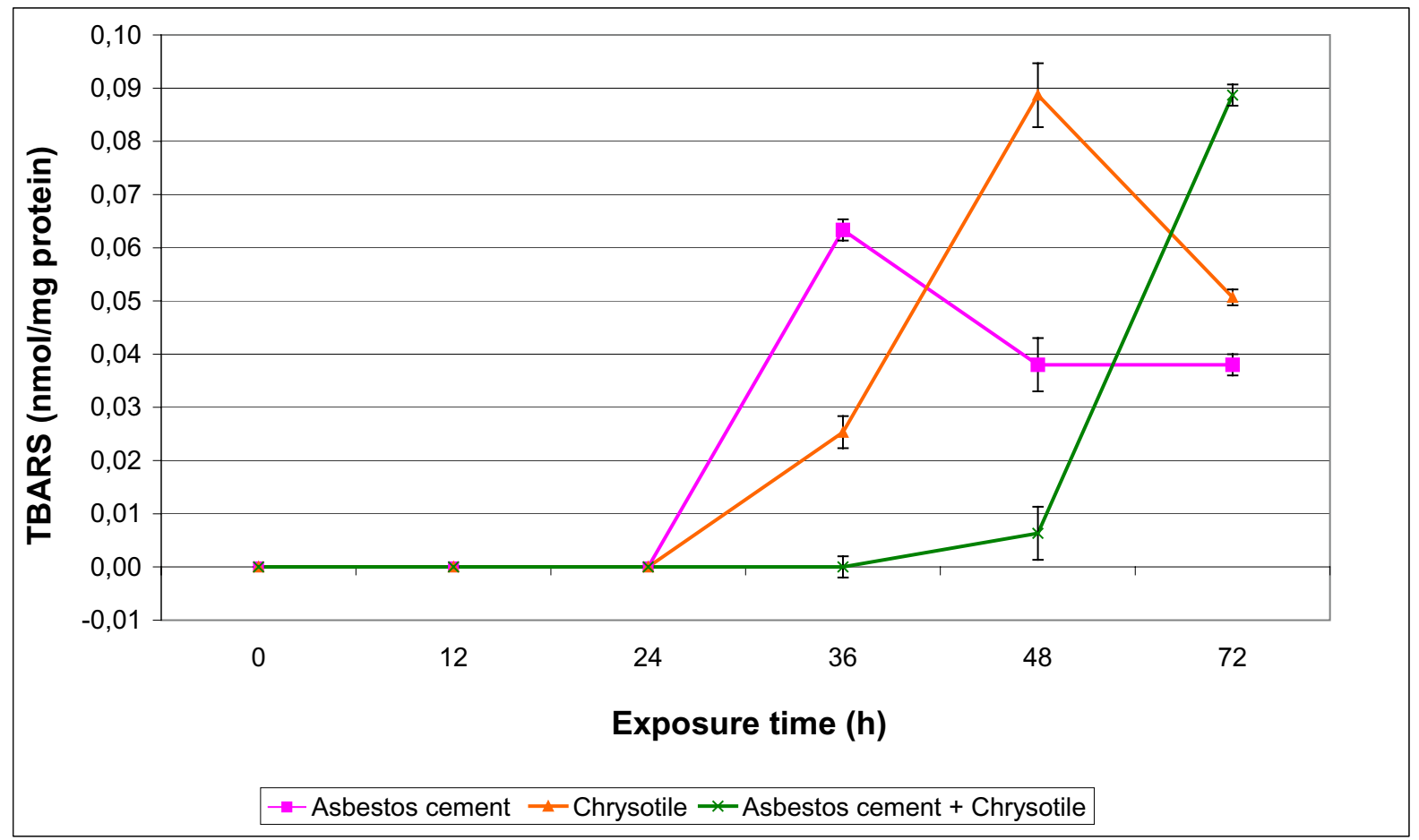

\section{Figure 6}

Thiobarbituric acid-reactive substances (TBARS) released by V79-cells exposed to asbestos-cement $\left(3 \mu \mathrm{g} / \mathrm{cm}^{2}\right)$, chrysotile $(\mathrm{I}$ $\left.\mu \mathrm{g} / \mathrm{cm}^{2}\right)$ or asbestos cement and chrysotile in co-exposure. The experiment was repeated twice. Significance: $* \mathrm{p}<0.05$

chrysotile $\left(1 \mu \mathrm{g} / \mathrm{cm}^{2}\right)$ or asbestos cement and chrysotile in co-exposure for $6 \mathrm{~h}, 12 \mathrm{~h}, 24 \mathrm{~h}, 36 \mathrm{~h}, 48 \mathrm{~h}$, and $72 \mathrm{~h}$. Cells cultured in Ham's F12 medium were used as negative control. After the different exposure times, $1 \mathrm{ml}$ of the probe was mixed with $200 \mu$ liced trichloracetic acid (30\%) to precipitate the protein and thereafter centrifuged at $10,000 \mathrm{rpm}$ for $5 \mathrm{~min}$. Further, $1 \mathrm{ml}$ of the supernatant was incubated with $500 \mu \mathrm{l}$ thiobarbituric acid (1\%) in a water bath at $95^{\circ} \mathrm{C}$ for $10 \mathrm{~min}$. After centrifuging at 3000 $\mathrm{rpm}$ for $5 \mathrm{~min}$, the absorbance of the supernatant was measured in a spectral photometer at $532 \mathrm{~nm}$. The amount of TBARS formed was expressed as malondialdehyde (MDA) equivalents in the supernatant. The concentration of the TBARS was calculated by a calibration curve (standard substance: 1, 1, 3, 3-tetramethoxypropane, Sigma, Germany). The experiments were performed in duplicates.

\section{Statistical analysis}

The chi ${ }^{2}$-test was used for comparison of micronucleus and kinetochore results with the untreated control in each set of experiments.

\section{Competing interests}

The author(s) declare that they have no competing interests.

\section{Authors' contributions}

QR had the initial idea of performing the investigations together with ED, who had coordinated the experiment and had edited the final version of the manuscript. SY and SG have carried out the genotoxicity studies. KB had drafted the manuscript and BS had participated with him in the genotoxicity studies with different iron chelators. UvR has done the cytotoxicity studies and the TBARS assay with help of UR. FAA had done the light microscopic study of the samples. Finally, KR had done the electron microscopic study of the samples. All authors read and approved the final manuscript. 


\section{Acknowledgements}

We thank Gabriele Zimmer, Ute Zimmermann and Mohd. Ashquin for their excellent technical assistance. We are also thankful to the Director of the Industrial Toxicology Research Centre, Lucknow, and Human Resource Development of Council of Scientific and Industrial Research, India, for providing facilities. The authors thank Prof. Dr. Gerrit M. Alink (Wageningen University, The Netherlands) for critical reading of the manuscript.

\section{References}

I. Mossman BT, Bignon J, Corn M, Seaton A, Gee JB: Asbestos: scientific developments and implications for public policy. Science 1990, 247(4940):294-30।.

2. Paris C, Beniuchou J, Saunier F, Matayer J, Brochard P, Thiberville L, Nouvet G: Smopking status, occupational asbestos exposure and bronchial location of lung cancer. Lung Cancer 2003, 40:17-24.

3. Rahman Q, Dopp E, Lohani M, Schiffmann D: Occupational and environmental factors enhancing the genotoxicity of asbestos. Inhal Toxicol 2000, I 2: I57-165.

4. Landrigan PJ: Asbestos-still a carcinogen. N Engl J Med 1998, 338:1618-9.

5. Shukla A, Ramos-Nino M, Mossman B: Cell signaling and transcription factor activation by asbestos in lung injury and disease. Int J Biochem Cell Biol 2003, 35(8): 198-209.

6. Guthrie G, Mossman B, Eds: Health effects of mineral dusts. Volume 28. Minerological Society of America, Washington D.C; 1993: I-584.

7. Kamp DW, Weitzman SA: The molecular basis of asbestos induced lung injury. Thorax 1999, 54:638-652.

8. Lim HH, Rampal KG, Joginder S, Bakar CM, Chan KH, Vivek TN: Respiratory conditions of Malaysian asbestos cement workers. Med J Malaysia 2002:340-347.

9. Light W, Wei E: Surface charge and asbestos toxicity. Nature 1977, 265:537-539.

10. Rahman Q: Asbestos: An occupational and environmental carcinogen. In Mining and Environment Edited by: Dhar BB, Thakur DN. Oxford \& IBH Publ. Co. Pvt. Ltd., New Delhi; 1995:549-564.

II. Spurny KR: Asbestos fibre release by corroded and weathered asbestos-cement products. IARC Sci Publ 1989, 90:367-7I.

12. Dušinská M, Collins A, Kazimirova A, Barancokova M, Harrington V, Volkovova K, Staruchova M, Horska A, Wsolova L, Kocan A, Petrik J, Machata M, Ratcliffe B, Kyrtopoulos S: Genotoxic effects of asbestos in humans. Mutat Res 2004, 553(I-2):91-102.

13. Kim HN, Morimoto Y, Tsuda T, Ootsuyama Y, Hirohashi M, Hirano T, Tanaka I, Lim Y, Yun IG, Kasai H: Changes in DNA 8-hydroxyguanosine formation levels, 8-hydroxyguanosine repair activity, and hOGGI and hMTHI mRNA expression in human lung alveolar epithelial cells induced by crocidolite asbestos. Carcinogenesis 200I, 22:265-269.

14. Fung H, Kow YW, Van-Houten B, Mossman BT: Patterns of 8hydroxydeoxyguanosine formation in DNA and indications of oxidative stress in rat and human pleural mesothelial cells after exposure to crocidolite asbestos. Carcinogenesis 1997, I 8:825-832.

15. Smailyte G, Kurtinaitis J, Andersen A: Mortality and cancer incidence among Lithuanian cement producing workers. Occup Environ Med 2004, 6 I (6):529-534.

16. Fatima N, Jain AK, Rahman $Q$ : Frequency of sister chromatid exchange and chromosomal aberrations in asbestos cement workers. Br J Ind Med I991, 48:103-105.

17. Rahman Q, Prasad R, Das M, Pandey US, Ashquin M, Lohani M: Follow up study in an asbestos cement factory with special emphasis on preventive and diagnostic measures. Project: Industrial Toxicology research Centre, India, Annual Report 1996.

18. Hong YC, Choi SS: Cytotoxicity and multinucleate giant cell formation in Chinese hamster lung fibroblast caused by crocidolite and chrysotile. J Korean Med Sci 1997, I 2(2):99-104.

19. Dopp E, Poser I, Papp T: Interphase FISH detection of cell cycle genes in asbestos-treated human mesothelial cells, MeT-5Aand mesothelioma cells. Cell Molec Biol 2002, 48:OL 27I-OL 277.

20. Lohani M, Yadav S, Schiffmann D, Rahman Q: Diallylsulfide attenuates asbestos-induced genotoxicity. Toxicol Lett 2003, | 43:45-50.
21. Poser I, Rahman Q, Lohani M, Yadav S, Becker HH, Weiss DG, Schiffmann D, Dopp E: Modulation of genotoxic effects in asbestosexposed primary human mesothelial cells by radical scavengers, metal chelators and a glutathione precursor. Mutat Res 2004, I I:559( I-2): 19-27.

22. Bhattacharya K, Yadava S, Papp T, Schiffmann D, Rahman Q: Reduction of chrysotile asbestos-induced genotoxicity in human peripheral blood lymphocytes by garlic extract. Toxicol Lett 2004, I 53(3):327-32.

23. Dopp E, Schuler M, Schiffmann D, Eastmond DA: Induction of micronuclei, hyperdiploidy and chromosomal breakage affecting the centric/pericentric regions of chromosomes I and 9 in human amniotic fluid cells after treatment with asbestos and ceramic fibers. Mutat Res 1997, 377:77-87.

24. Dopp E, Schiffmann D: Analysis of chromosomal alterations induced by asbestos and ceramic fibers. Toxicol Lett 1998, 9697:155-62.

25. Burmeister B, Schwerdtle T, Poser I, Hoffmann E, Hartwig A, Muller WU, Rettenmeier AW, Seemayer NH, Dopp E: Effects of asbestos on initiation of DNA damage, induction of DNA-strand breaks, P53-expression and apoptosis in primary, SV40transformed and malignant human mesothelial cells. Mutat Res 2004, 558(I-2):8I-92

26. Abidi P, Afaq F, Arif JM, Lohani M, Rahman Q: Chrysotile-mediated imbalance in the glutathione redox system in the development of pulmonary injury. Toxicol Lett 1999, I06(I):31-9.

27. Afaq F, Abidi P, Rahman $Q$ : N-acetyl L-cysteine attenuates oxidant-mediated toxicity induced by chrysotile fibers. Toxicol Lett 2000, I I 7( I-2):53-60.

28. Kopnin PB, Kravchenko IV, Furalyov VA, Pylev LN, Kopnin BP: Cell type-specific effects of asbestos on intracellular ROS levels, DNA oxidation and GI cell cycle checkpoint. Oncogene 2004, 23:8834-8840.

29. Tilkes F, Beck EG: Cytotoxicity and carcinogenicity of chrysotile fibres from asbestos-cement products. IARC Sci Publ 1989, 90:190-196.

30. Trivedi AK, Ahmad I, Musthapa MS, Ansari FA, Rahman Q: Environmental contamination of chrysotile asbestos and its toxic effects on growth and physiological and biochemical parameters of Lemna gibba. Arch Environ Contam Toxicol 2004, 47(3):281-9.
Publish with Bio Med Central and every scientist can read your work free of charge

"BioMed Central will be the most significant development for disseminating the results of biomedical research in our lifetime. "

Sir Paul Nurse, Cancer Research UK

Your research papers will be:

- available free of charge to the entire biomedical community

- peer reviewed and published immediately upon acceptance

- cited in PubMed and archived on PubMed Central

- yours - you keep the copyright

Submit your manuscript here:

http://www.biomedcentral.com/info/publishing_adv.asp
BioMedcentral 